MARK LILLA

Lekkomyślny umysł. Intelektualiści w polityce (Reckless Mind)

Przeł. Janusz Margański

Prószyński i S-ka, Warszawa 2006, ss. 184

\title{
MARTA DORENDA
}

Instytut Politologii UMK

\section{Lustracja po amerykańsku}

2 iedy w 2001 r. w Nowym Jorku opublikowano pierwsze, jeszcze nietłu-

maczone na inne języki, wydanie książki Marka Lilli, zatytułowanej Lekkomyślny umyst, Łukasz Tischner napisał w „Tygodniku Powszechnym”, iż jest to „lektura odświeżająca i pouczająca, zwłaszcza nad Wisłą” ${ }^{1}$. Okazać się miało, że w roku wydania „Lekkomyślnego umysłu” w Polsce lektura pozostała zarówno aktualna, jak i pouczająca, jednakże panująca nad Wisłą atmosfera ujawniania kolejnych wątków związanych z lustracją odebrała książce wszelką świeżość.

Jej tytuł oraz treść można odwołać zarówno do słów Solona („We wszystkich was tkwi lekkomyślny umysł. Język bowiem i słowa pochlebcy widzicie, na to zaś, co się dzieje, spojrzeć nie umiecie”), jak i do dzieła Miłosza. Autor już w przedmowie zaznacza, iż traktuje książkę jako „skromne pendant do Zniewolonego umysłu" (s. 11), za przedmiot rozważań obierając związki dwudziestowiecznych myślicieli z reżimami niedemokratycznymi. Podobnie jak noblista, ukazujący niszczącą siłę komunizmu nie poprzez pryzmat fizycznej przemocy, lecz niebezpiecznego zauroczenia ideologią, zmieniającego ludzkie charaktery i skłaniającego światłych przecież oraz świadomych sytuacji intelektualistów, Lilla przywołuje przykłady wybitnych europejskich twórców, których myśl do dziś jest żywa i stanowi źródło licznych inspiracji, przedstawiając jednocześnie jej podwaliny. Autor w kolejnych rozdziałach opisuje poszczególne postaci, próbując jednocześnie zreferować cały ich intelektualny dorobek, okoliczności jego powstania oraz osobowość omawianych filozofów. W pierwszej z siedmiu części analizie poddana zosta-

Ł. Tischner, Filozof w Syrakuzach, „Tygodnik Powszechny”, nr 28 (2776), s. 16. 
je relacja między Martinem Heideggerem, Hanną Arendt i Karlem Jaspersem. Uwadze Lilli nie uchodzi także karygodna przeszłość oraz flirty z totalitarnymi reżimami w wykonaniu Carla Schmitta, Waltera Benjamina, Alexandra Kojève'a (Aleksandra Kożewnikowa), Michela Foucault oraz Jacquesa Derridy. Ostatni rozdział, zatytułowany Urok Syrakuz, odnoszący się do podróży Platona na dwór Dionizjosa, ma stanowić wspólny mianownik dla każdego z zamieszczonych w książce esejów oraz uzasadniać stanowisko autora.

Lilla stawia siebie samego na pozycji niezależnego obserwatora obiektywnych faktów. Usiłuje przekonać czytelnika nie tyle o własnej neutralności, bezstronności, co wręcz o przychylności żywionej dla opisywanych postaci - jak sam pisze, „nie zamierza podsuwać czytelnikom pretekstu, żeby zbyć te postaci jako $\mathrm{w}$ jakiś sposób przekraczające granice przyzwoitości" (s. 12). Zapewnia, iż jego celem było jedynie ukazanie aberracji; niepokojących, jeśli nie groźnych zjawisk, zachodzących, gdy intelektualiści, filozofowie, wiążą się z władzą - „gdy pewne charaktery, pewne typy umysłowości zostają wrzucone w wir polityki” (s. 10). Uznaniem darzy „myślicieli i pisarzy żyjących za żelazną kurtyną (...), którzy znosili to godnie - jak tylko mogli, opierali się przekupstwom i groźbom tyrana" (s.10). Deklaruje iż tych, którzy „dołączyli do chóru”, chce traktować ze zrozumieniem, jeśli nie pobłażliwością, przyznając, że „tym z nas, którzy nigdy nie stawili czoła takim wyborom, nie jest łatwo osądzić to, co zrobili” (s. 10). Na każdym kroku temu zaprzeczając, Lilla podejmuje się jednak wydania osądu. Trudno jest znaleźć punkt wyjścia krytyki, której dokonuje, nie przysparza zaś kłopotu odnalezienie w książce sprzeczności. Z jednej bowiem strony autor odrzuca jakiekolwiek historyczne wyjaśnienie problemu, zdając się na poszukiwanie uproszczonych psychologicznych wytłumaczeń, z drugiej zaś przyznaje, iż polityczne inklinacje mogą czerpać swe źródła z historii. Krytykuje historyków idei, zarówno tych, wzorem Izajasza Berlina, wywodzących uzasadnienia dla związków intelektualistów ze zbrodniczymi reżimami z idei oświeceniowych, jak i tych, którzy przyczyn szukają w religijnym irracjonalizmie, podobnie jak Norman Cohn. Lilla przyznaje rację historykom, w tym historykom idei, by chwilę później zarzucić im niekonsekwencję, niespójność oraz niekompletność badań. W zamian proponuje „inny sposób badania intelektualnej filotyranii" (s. 165), polegający na poszukiwaniu w życiorysach opisywanych postaci punktów stycznych, właściwych tym, którzy dali się uwieść totalitaryzmom: podobnych rysów życia rodzinnego, nawiązań do teologii, badania ich historii pod kątem przemocy i konfliktu. Szukając potwierdzenia obranej przez siebie tezy, autor skupia się na religijnych inklinacjach, nieudanych małżeństwach w przypadku Heideggera i Benjamina lub na sensacyjnej rozwiązłości życia prywatnego Foucault. Lilla zdaje się nie 
wiedzieć czy przyklasnąć Aronowi, darzącemu dezaprobatą tych, którzy ulegli „opium intelektualistów” i zniżyli się do poziomu zaangażowania w politykę, czy raczej Habermasowi, zarzucającemu tym, którzy się owej pokusie oparli, bycie „wieżą z kości słoniowej”.

Po lekturze, przybliżającej czytelnikowi wszelkie dewiacje, występki oraz odstępstwa od moralnej normy, których dopuścili się przywołani w książce myśliciele, trudno jest uwierzyć w deklaracje autora, chcącego rzekomo jedynie przybliżyć prawdę. Trudno orzec czy Lekkomyślny umysł obliczono na udowodnienie nieszczególnie oryginalnej opinii, iż filozofowie nie powinni oddawać się w służbę żadnej, choćby najbardziej nęcącej ideologii, czy też na wstrząśnięcie tymi, którzy o politycznych uwikłaniach intelektualistów nie wiedzieli (co rzadko spotykane) lub próbowali - jakże, zdaniem autora, lekkomyślnie - docenić ich twórczość nieskażoną totalitaryzmem. Lilli, z inkwizytorską pasją tropiącemu wszelkie z nim związki, nie udaje się uniknąć przykrawania faktów na potrzeby założonej tezy. 0 ile bowiem wybór postaci Heideggera czy Schmitta można uznać za zrozumiały, sam autor przyznaje, iż trudno równie skutecznie skrytykować Benjamina lub Derridę. Atakując Kojève’a, Lilla przyznaje, iż ten „nigdy nie zajmował oficjalnego stanowiska, które pozwoliłoby sprawdzić jego stanowczość" (s. 114). W rozdziale dotyczącym Foucault najpoważniejszym stawianym filozofowi zarzutem jest jego homoseksualizm oraz życie prywatne nieprzystające do konwencjonalnych zasad moralnych, co $\mathrm{w}$ niewielkim stopniu związane jest z wyraźnie podkreślaną tematyką książki. Co najistotniejsze, autor, wbrew zapowiedziom, nie szuka wyjaśnień, dąży zaś do potwierdzenia z góry obranej tezy. Z żadnego z rozdziałów Lekkomyślnego umysłu nie dowiadujemy, się jakie motywacje kierowały filozofami. Zadziwiające to niedopatrzenie $\mathrm{w}$ obliczu dokładności, z jaką przytacza się szczegóły świadczące na ich niekorzyść.

Zręczne żonglowanie frazami (świadczącymi tak o erudycji, jak i o sumiennym doszukaniu się wszelkich dostępnych materiałów pogrążających podsądnych) nie zamaskowało obranego przez autora stanowiska moralistydemaskatora, powierzchownie przyznającego etykiety. Podejmuje on wysiłek przedstawienia wyjaśnień określonych zachowań, jednak nie dopuszcza ich usprawiedliwiania. Oskarżenia, które wystosowuje, nie zawsze poparte są faktami - dość przywołać przykład Heideggera, którego antysemityzm zostaje arbitralnie, bez wyjaśnienia stwierdzony (s. 34). Uzasadnienia samych „zainteresowanych” są ironicznie torpedowane jako „bezwstydne samousprawiedliwienia i nieodpowiedzialne spekulacje polityczne" (s. 37). Lilla z jednej strony próbuje prześledzić duchowe biografie wybranych przez siebie filozofów, by zrozumieć decyzje, które podejmowali, z drugiej zaś - wie- 
dza, którą zdobywa, oraz choć częściowa rekonstrukcja okoliczności, nie skłania go choćby do złagodzenia wydanych wyroków. Z jednej strony prezentuje się jako badacz, przypisując sobie iście weberowski obiektywizm, z drugiej zaś nie jest w stanie przezwyciężyć „wewnętrznej odrazy” (s. 176). Przyznaje on bowiem, że tym, co łączy filozofa z tyranem, jest poddanie się Erosowi. To miłość skłania jednego lub drugiego w stronę mądrości lub despotyzmu. Filozofem może być jednak tylko ten, kto jest owej siły świadom i posiadł nad nią władzę. Heidegger, Schmitt, Foucault i inni zajęli niewłaściwe stanowisko. Kończąc wywód, Lilla bierze pod uwagę wykazanie wyrozumiałości, zajęcia ludzkiego stanowiska: „Może więc powinniśmy przymknąć oko na polityczne pomyłki europejskich intelektualistów i spróbować zrozumieć ich, biorąc pod uwagę skrajne sytuacje w dwudziestym wieku (...)" (s. 176). Szybko jednak zwalcza tę pokusę, zauważając, iż „popełniłby błąd, gdyby jej uległ" (s. 176). Filozof nie może wszak pozwolić sobie na tak niegodne czyny.

Piętrowe metafory Lilli, przystępny język, którego używa, oraz eseistyczna swada nie odwracają uwagi od miałkiej treści. Wprawdzie, jak sam twierdzi, „na prawdziwość Euklidesowego dowodu nie wpływa to, w jaki sposób traktował swoich służących" (s. 11), na kolejnych stronach udowadnia, że gdyby Euklides traktował swoich służących źle, najlepiej byłoby jego twierdzenia przemilczeć. Zapewne jedynie wynikiem zbiegu okoliczności książka ukazała się $\mathrm{w}$ Polsce $\mathrm{w}$ dobie gorącej lustracyjnej debaty oraz w chwili, w której ważą się losy zachodnich demokracji. Niewątpliwie stanowi ona jednak do owych dyskusji przyczynek - zważywszy na entuzjastyczne przyjęcie polskiego wydania Lekkomyślnego umysłu, dla jednych jest on trafnym komentarzem bieżących wydarzeń oraz potwierdzeniem słuszności niestosowania ustępstw. W innych zaś książka Lilli budzi niesmak i skutecznie utrudnia nastanie owej „świeżości”, o której pisał Tischner. Porównanie Lekkomyślnego umystu do dzieła Miłosza wydaje się wysoce niestosowną uzurpacją. Oratorskie popisy Savonaroli w wykonaniu człowieka, któremu oszczędzona została konieczność wyboru między „przyłączeniem się do chóru" a zachowaniem własnej tożsamości, są nieuprawnione, podobnie jak nawiązania do noblisty, który przecież, gdyby konsekwentnie stosować kryteria obrane przez autora, zasługiwałby na potępienie. 